\title{
Theoretical Foundation of Business Model and Their Building Blocks
}

\author{
M. Suleman Sabir, Raja Mazhar Hameed, Kashif-ur-Rehman \& Ijaz-ur-Rehman \\ Department of Management Sciences, Iqra University, Islamabad Campus \\ 5, Khayaban-e-Johar, H-9 Islamabad, Pakistan \\ E-mail: msulemansabir@gmail.com
}

Received: July10, 2012

Accepted: August 28, 2012

Published: October 1, 2012

doi:10.5296/jmr.v4i4.2083

URL: http://dx.doi.org/10.5296/jmr.v4i4.2083

\begin{abstract}
Business model literature reviewed in multifaceted in which author example the business model concept through multidisciplinary and review reveals that scholars do not agree on the unified concept of business model that is why literature on business model dissects into multi-stream and become victim of abstruseness. The ambiguity on business model concept eradicate through providing theoretical ground, not on the empirical basis, therefore discussed variety of business definitions from 1998-2010 to come on the point of unified concept. Review the literature from 1996-2010 in sequential manners for building strong theoretical ground on building blocks, in this milieu found 28 blocks used in construction of business model. Companies often make substantial efforts to innovate their processes and products to achieve revenue growth that is why managers have well informed about the business model blocks. The study creates conceptual tools for both academic researcher and manager to develop future business model.
\end{abstract}

Keywords: Abstruseness, Activity, Conceptualization, Multidisciplinary, Origin 


\section{Macrothink}

\section{Introduction}

Business model (BM) term used as fashion in the era of dotcom boom and this increase the academic interest (Magretta, 2002; Shafer, Smith and Linder, 2005) some speak about business model for internet and other articulate about web business model. Massive literature on business model proposed (Morris, Schidehutte, and Allen, 2005; Johnson, Christensen, and Kagermann, 2008; Teece, 2010) and same case with business model building blocks (Osterwalder, 2004; Brousseau and Penard, 2006). Business model's description has been discussed in multidiscipline is including economics, innovation, management, strategy, ebusiness, and entrepreneurship (Amit and Zott, 2001; Hedman and Kalling, 2003; Teece, 2010) that is why business model concept has victim of complexity (Weill, Malone, and Apel, 2011).

Preceding researches have shown that citation of term business model in the papers increased (Osterwalder, Pigneir, \& Tucci, 2005; Makinen \& Seppanen, 2007). The publications on the business model escalation have confirmed through Google Trend $^{1}$ which shown business model term searches on the Google from 2004 to 2012. This study dloes not depict the downloading trend but confirm the above discussion that concept of business model has not still explicitly defined and business model term is victim of vague.

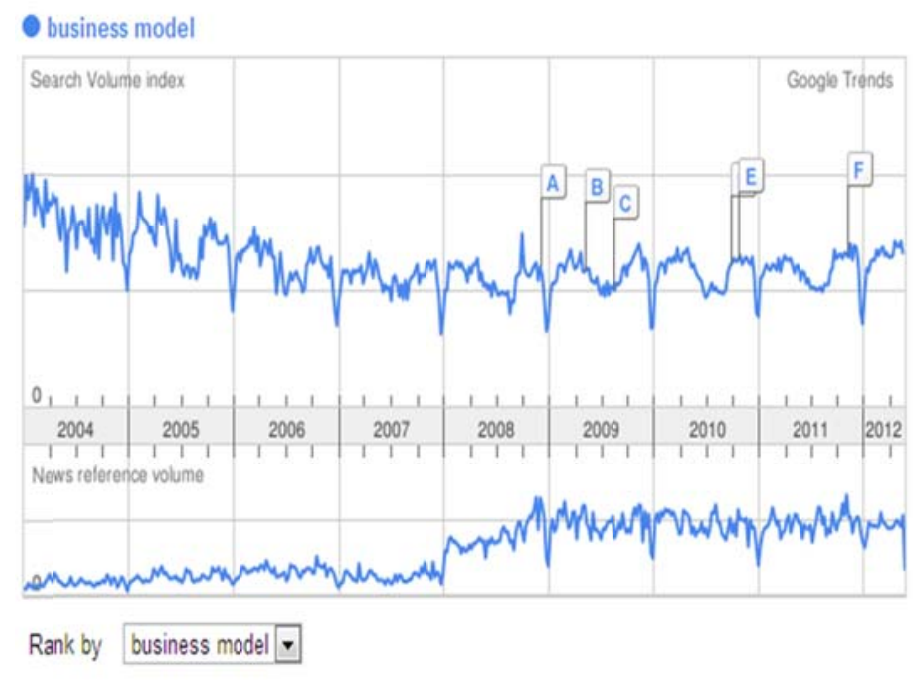

Fig. 1.1 Download trend of term business model

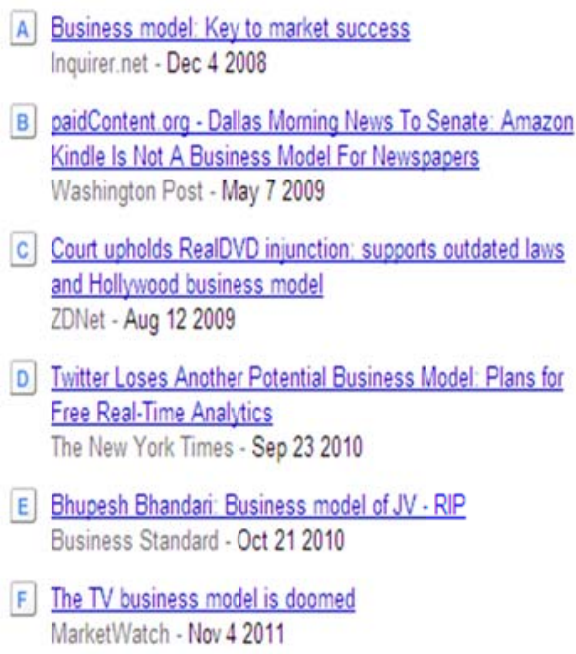

Business model: Key to market success

paidContent org - Dallas Moming News To Senate: Amazon Kindle Is Not A Business Model For Newsoapers washington Post - May 72009 and Hollywood business mode ZDNet - Aug 122009

Twitter Loses Another Potential Business Model: Plans for Free Real-Time Analytics

The New York Times - Sep 232010

Bhupesh Bhandari: Business model of JV. RIP Business Standard - Oct 212010

MarketWatch - Nov 42011

Business model has received lot of attention from managers, entrepreneur, investors, consultant, and academic. Every company has a business model whether that model is explicitly articulate or not. Business model made possible for organization to enact commercial opportunities and gives opportunity to the managers to create, deliver, and capture values in efficient way and can be explore for future development. This study based on previous literature and will identify building blocks from different studies, due to the

\footnotetext{
${ }^{1}$ www.google.com/trend
} 
variation in use of term business model and time limitation, therefore study bounded with habitual use of building blocks. This study will enhance the understanding of business model by presenting the early definitions and providing comprehensive discussion on the each stream of business model definition for generation of unified concept.

\section{Literature Review}

\subsection{Business Model Roots}

Business model has to answer a series of questions essential to any business. Business model concept is drawn from the Peter Drucker's questions; who is customer, what does value and how does intend to earn wealth (Drucker, 1954; Magretta, 2002). Chesbrough and Rosenbloom (2002) elucidate the premises for the business model concept and found that origin of business model concept found in the literature of strategy from Chandler (1962) book of strategy and structure. In the same vein Amit and Zott (2001) and Hedman \& Kalling (2003) make clear in their research, that business model concept has originated in strategy literature. Preliminary study of (Makinen \& Seppanen, 2007) on business model with taxonomical research found that business model concept has been act as bridge between the strategy and operations. Welge and Al-Laham (2008) distinguished way of strategically thinking in an organization into four phases: financial planning phase, long-term planning, strategic planning phase, and strategic management. These evidences confirm that business model research originated in strategic management.

\subsection{Early Views on Business Model}

The early authors have mainly written about the classification of models in different categories; Business model classification based on the value proposition and revenue generation mode. First popular concept of business model is architecture of the product or service and information flow including description of actors, benefits, and revenue given by Timmers (1998). The method that provide sustainability to the company be considered right method while company clear about their revenue generation ways and made right position in the value chain (Rappa, 2001). Business model proposed by Tapscott, Lowy, and Ticoll (2000) based on business webs that depict how value exchange among the participants (partner, customer, and supplier) while different in their degree of economic control and value integration. Both authors (Tapscott, Ticoll, \& Lowy, Digital captial: Harnessing the power of business webs, 2000; Rappa, 2001) made more elucidation of revenue and product aspects rather than elucidation of business model elements. There are different actors involved in business model but based on three basic element including participants, relationship and flows (Weill \& Vitale, 2002) and also proposed eight atomic e-business models, each if which can be implemented as a pure business model or combined to create a hybrid model. Revenue generation and network aspect combined to define the business model (Osterwalder \& Pigneir, 2002; Morris, Schidehutte, \& Allen, 2005) for the focal organizations. Magretta (2002) and Afuah, A. (2004) have discussed the relationship between the strategy and business models. In the same vein, Seddon, Lewis, Freeman, \& Shanks, (2004) explore relationship of strategy with the business model. The research in business model address different aspects including definitions, conceptual business model, modules, 
taxonomies, tools for designing a model, and evaluation models (Pateli \& Giaglis, 2003). The business model researches shifted from the definitions and taxonomies toward building blocks, framework, and practical implementation. Osterwalder, Pigneur, and Tucci (2005), business oriented people have different concept of business model from the technology oriented. Diverse definition of business model from 1998 to 2010 has given in appendix I.

Osterwalder Pigneur and Tucci, (2005) group the definition of business model into activity related and value oriented approaches. In the same line, (George \& Bock, 2011) categorized the business model definition into organizational designing, resources based, sense making, nature of innovation and opportunity. Zott, Amit, \& Massa (2010) divided the business model stream of thoughts into three main schools of thoughts: e-commerce school of thoughts, strategy school of thoughts and technology, \& innovation management school of thoughts for better understanding of business model concept. First school of thought is e-commerce that gives explanation on business model in context of internet-based businesses and firm's role in their own ecosystem. Next one is strategy school of thoughts in which business model used to explain value creation process and which sources used to gain sustainable competitive advantage. Technology \& innovation management school of thoughts see a business model as commercialization aspects of technology and innovation. These schools of thought give the opportunity to researcher and reader study the business model concept in their domain. Classically, business model definitions revolved around the value creation, capturing, and delivering (Osterwalder \& Pigneur, 2010; Teece, 2010). For example Chesbrough (2006) affirm that value creation and value capturing are main functions of the business model. Osterwalder and Pigneur (2010) state that business model describe as how value is created, captured and delivered by an organization. Teece (2010) made description of business model as how firm create and deliver the value to customer and in return gain profit. Ghaziani and Ventresca (2005) concluded that most discussed frame of business model is value. In the same vein Zott, Amit and Massa (2010) come to point that typically authors discussed value aspect in defining the business model. While meaning of value perceived in different respects for example customer value aspect discussed by (Tapscott, 2001; Dubosson-Torbay, Osterwalder, \& Pigneur, 2002; Osterwalder \& Pigneur, 2010; Teece, 2010) both customer value and company value consider by (Bouwman, Vos, \& Haaker, 2008; Johnson, Christensen, \& Kagermann, 2008) and economic value describe by (Gordijn \& Akkermans, 2001).

\subsection{Business Model Buidling Blocks}

Internet boom period gave opportunity of creating values in variety of ways for customer (Amit and Zott, 2001). The research on e-commerce business model perspective has been classified in multiplicity of ways for example Timmer (1998) differentiate among 11 models, Weill and Vitale (2001) presented another classification of business model based service, content provider, direct to customer, intermediary, virtual communication, value integration and share infrastructure. Mahadevan (2000) presented value, revenue, and logistic stream for business model construction. This perception extended by Osterwalder (2004) through presenting framework of value proposition, network of actors, distribution channels, customer segment and revenue generation. Pauwels and Weiss (2008) present a survey of 
customer shifting from free to paid services through marketing. Casadesus-Masanell and Ricart (2010) highlight the business perspective for firm as realization of strategy. Researches on business model regarding technology perspective divided into two main streams; commercially enact of innovation and new dimension of innovation. Chesbrough (2010) emphasized on the removal of complexity to adjust with existing resources and inability to see new idea. Giesen, Berman, Bell, and Blitz (2007) proposed three business model type, supply chain, revenue generation and innovation position.

Business model has break down into various parts such as Osterwalder, Pigneir, and Tucci, (2005) suggest nine modules, Mason and Spring (2010) offer three components, Johnson, Christensen, and Kagermann (2008) supply four parts of business model. However, various other researchers presented different dimension / modules of business model. For example Weil and Vitale (2001) offer business model schematics with four characteristics; required competencies, success factors, revenue generation and strategic and value proposition. Chesbrough and Rosenbloom (2002) discussed the business model as mediating role between the technology and economic value. Morris, Schidehutte, and Allen, (2005) developed business model for entrepreneurship with intruding three level; foundation, proprietary and rules. E3-value ontology developed by Gordijn (2002) for e-business model through discussing actor role, exchange value, value port, group the value, value objects, market segment and value activity.

Diverse researches have conducted for exploration of business model elements. Shafer, Smith, and Linder (2005) found 42 different building blocks and proposed four major block; strategic choice, value network, create value and capture value. Same work has been extended (Krcmar, Bohm, Friesike, \& Schildhauer, 2011) by presenting 27 elements of business model through consulting 28 different authors from 1996-2010. The early authors have mainly written about the frameworks in different categories; Business model frameworks classification based on the value proposition and revenue generation mode. Business model compiled with elements/ modules, and referred as building blocks. Palo \& Tahtinen (2011) differentiate the literature of business model based on single firm and business net.

\section{Research Method}

The research program has developed comprising of three steps strategy to meet with the objective of the study. First, design a research schema for reviewing the literature or accessing the secondary data sources for building strong theoretical grounding on business model concept. Second step involve identification of business model building blocks in chronological order. For this purpose, arrange the building block with researcher's name in an excel sheet. Third strategy involve habitual exploitation of each building block usage from 1996-2010. This study laced the manager with knowledge of different building blocks which components are most important for the business because success of firm depends on the adaptation of right business model and fill the gap between the academics and practitioners.

\subsection{Research Schema}

For reviewing the literature in sequential manner, adopt road map of business model research work which is extension of Weiner, Renner, and Kett (2010) research. The research map 
contains 55 authors studies in which 30 authors highlight different modules of business model. Figures comprises with different line colors, where each color line indicate road of research regarding business model. Authors address definitions on green line, business model component on orange line, business model classification depict with red color line, transformation approaches of business model in brown line, business model design, methods and tool have given in turquoise color, and business model evaluation lay on blue line.

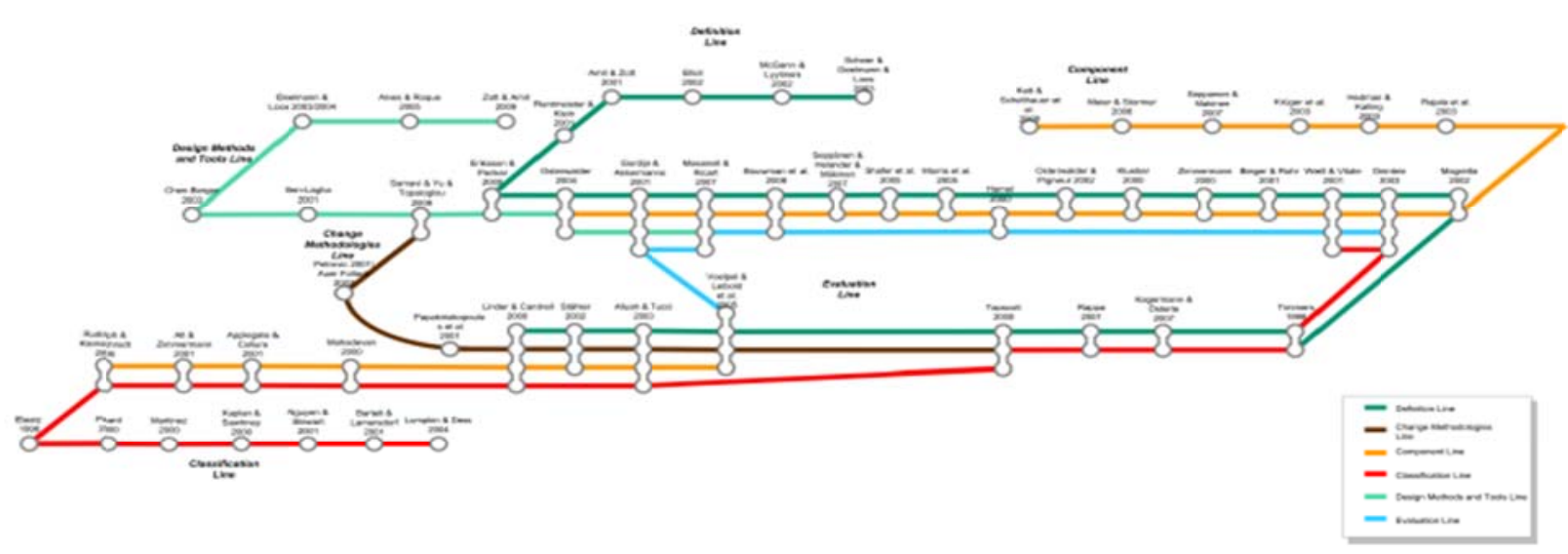

Figure 1: Business Model Research Map

Source: Weiner et al. (2010)

Fraunhofer Institute of Industrial Engineering (IAO); Competence Centre Electronic Business (sponsor by German THUSEUS program) build a website ${ }^{2}$ that makes available information on the business model for information technology. Publications on the business model concept around the world have consolidated so that numerous articles regarding the business model available on the website. Another online community ${ }^{3}$ has established for development of research, that share the theoretical grounding and empirical researches on the business model to create knowledge.

Ghaziani and Ventresca (2005) consult 1729 publication regarding the business model; Zott, Amit, and Massa (2010) review more than 1300 business journals and presented more complete source of literature on business model roots and its development. In the same vein (Krcmar, Bohm, Friesike, and Schildhauer, 2011) presented road map of business model research work; Palo and Tahtinen (2011) differentiate the literature of business model on the basis of single firm and business net. Kim and Im (2012) present the classification of business model ontology through K-means algorithm and analyze business model components of patent data. However, examined business model concept through multiple disciplinary but reveal that scholars do not agree on what building blocks of business model shown in appendix II.

\footnotetext{
2 www.itbusinessmodels.org

${ }^{3}$ http://www.businessmodelcommunity.com
} 


\section{Macrothink}

\subsection{Identification of Building Blocks}

The study on business model building block conduct through reviewing the literature in chronological order and found various researches on business model while all used elements present in table form in appendix III with description of researchers and their blocks. However, 28 business model building blocks has identified through reviewing the 62 authors' literature on business model building blocks from1996-2010.

\subsection{Habitual Exploitation of Building Blocks}

Reviewing the recent literature on business model (Ghaziani and Ventresca, 2005; Zott, Amit, and Massa, 2010; Krcmar, Bohm, Friesike, and Schildhauer, 2011; Palo and Tahtinen, 2011; Kim and Im, 2012) and other various publications of indexed journals. However, supply a table of building block of business model in appendix II from 1996 to 2010 and from this, indentified statistics on the business model building blocks exploitation. Use the tally marks for determining the each building block number of observations. A tabular arrangement of business model modules has made into different classes with corresponding class frequency has given in appendix IV based on appendix III.

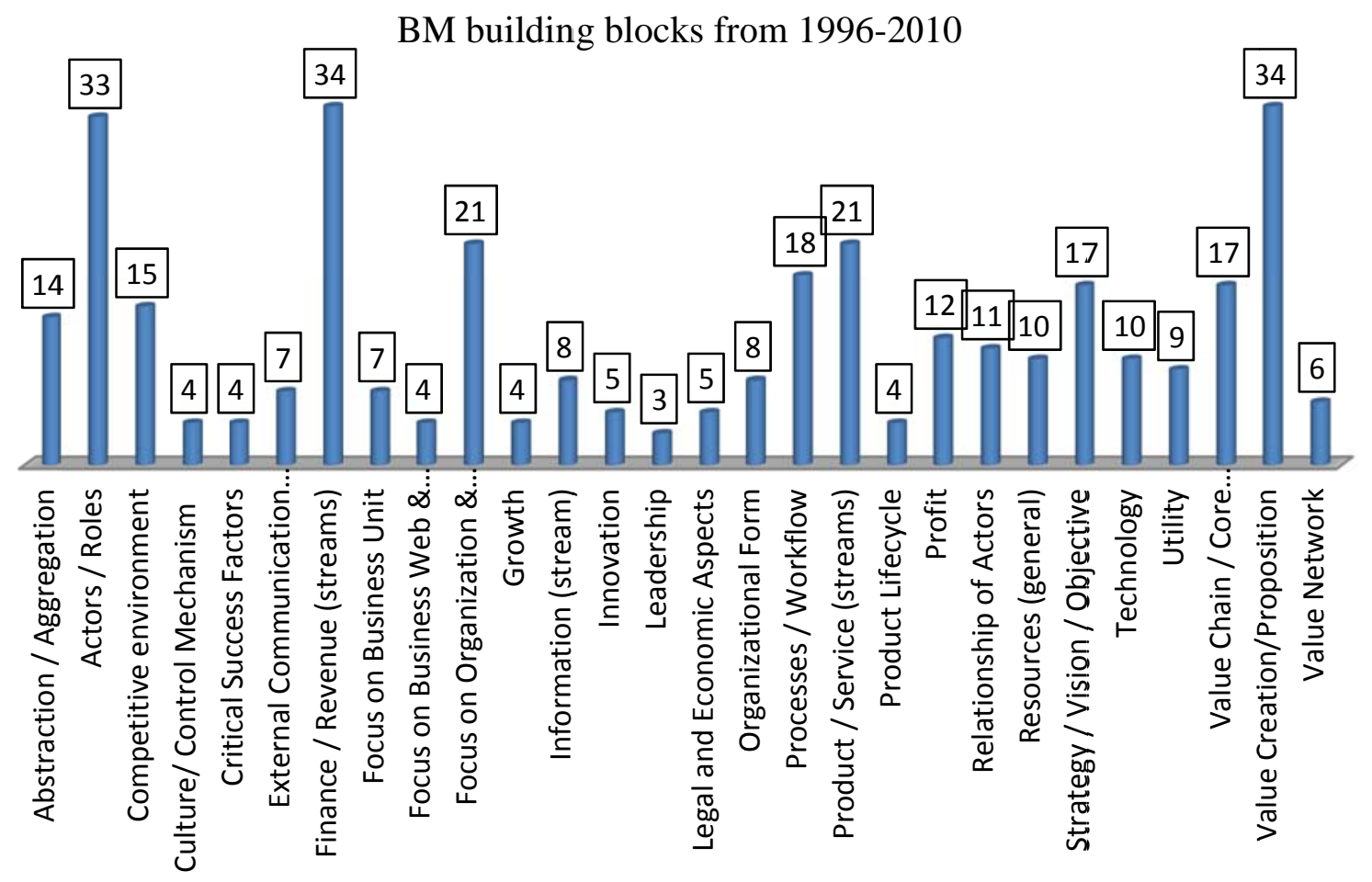

\section{Conclusion}

Business model knowledge impart through adopting diverse unit of analysis such as organization, business, company, organizational level, organizational entity and some time 
network level. Purpose of business model is different in dissimilar context for instance starting phase and growth phase of a company, variety of innovation and technology, profit, and not-for-profit organizations, and importance of technology, innovation vary from organization to organization. These make the harder to build the well-defined and strong conceptualization grounding for business model concept. Classically, business model concept revolved around the value creation, capturing, and delivering (Osterwalder \& Pigneur, 2010; Teece, 2010). For example Chesbrough (2006) affirm that value creation and value capturing are main functions of the business model. Osterwalder and Pigneur (2010) state that business model describe as how value is created, captured and delivered by an organization. Teece (2010) made description of business model as how firm create and deliver the value to customer and in return gain profit. Ghaziani and Ventresca (2005) concluded that most discussed frame of business model is value. In the same vein Zott, Amit and Massa (2010) come to point that typically authors discussed value aspect in defining the business model. While meaning of value perceived in different respects for example customer value aspect discussed by (Osterwalder \& Pigneur, 2010; Teece, 2010) both customer value and company value consider by (Bouwman, Vos, \& Haaker, 2008; Johnson, Christensen, \& Kagermann, 2008) and economic value describe by (Gordijn \& Akkermans, 2001). However, Business model can be too abstract because there are various opinions on the concept of the model, and therefore, can cause confusion. For unified concept, drawing from the above discussion that business model as a system of interconnect and interdepent activities that determines the way the company does business with its customer, partner and vendors. Business model is unified as a set of specific activites conducted to satisfy the perceieved needs of the market and how these activites linked with each other. Business model constructed with 28 diverse blocks used by 62 authors in different time. Diverse blocks used in previous researches for building the business model, but now researcher can identified in glance frequently used and imperative blocks of the business model. This compilation offer glimpse over the business model blocks and act as complete source of literature on business model. Business model determine the success or failure of strategies that is why organizations need innovation encouraging environment; in this context, companies often make substantial efforts to innovate their processes and products to achieve revenue growth and to maintain or improve profit margins that is why need to further explore these habitual blocks in business model practices.

\section{References}

Afuah, A. (2004). Business model: A strategic management approach. New York: McGraw Hill/Irwin.

Amit, R., \& Zott, C. (2001). Value creationi n E-business. Strategic Management journal, 22(6-7), 493-520. http://dx.doi.org/10.1002/smj.187

Bouwman, H., Vos, H. D., \& Haaker, T. (2008). Mobile service innovation and business models. Springer Berlin Heidelberg. http://dx.doi.org/10.1007/978-3-540-79238-3_12

Brousseau, E., \& Penard, T. (2006). The economics of digital business models: A framework for analyzing the conomics of platforms. Review of network Economics, 6(2), 81-110. 


\section{Macrothink}

Journal of Management Research

ISSN 1941-899X

2012, Vol. 4, No. 4

Casadesus-Masanell, R., \& Ricart, J. E. (2010). From strategy to business models and onto tactics. Long Range Planning, 43(2-3), 195-215. http://dx.doi.org/10.1016/j.lrp.2010.01.004

Chandler, A. (1962). Strategy and structure. Cambridge: MIT press.

Chesbrough, H. (2006). Open business model: How to thrive in the new innovation landscape. Harvard Business School Press.

Chesbrough, H. (2010). Business model innovation: Opportunities and Barriers. Long Range Planning, 43, 354-363. http://dx.doi.org/10.1016/j.lrp.2009.07.010

Chesbrough, H., \& Rosenbloom, R. (2002). The role of the business model in capturing value from innovation: evidence from Xerox Corporation's technology spin off companies. Industrial and Corporate Change, 11(3), 529-55.

Drucker, P. (1954). The Practice of Management. New York: Harper and Row.

Dubosson-Torbay, M., Osterwalder, A., \& Pigneur, Y. (2002). E-Business model design, classification, and measurements. Thunderbird International Business Review, 44(1), 5-23. http://dx.doi.org/10.1002/tie.1036

George, G., \& Bock, A. (2011). The business model in practice and its implications for entrepreneurship research. Entrepreneurship Theory and Practice, 35(1), 83-111. http://dx.doi.org/10.1111/j.1540-6520.2010.00424.x

Ghaziani, A., \& Ventresca, M. (2005). Keywords and cultural change: Frome analysis of business model public talk 1975-2000. Sociological Forum, 20, 523-559. http://dx.doi.org/10.1007/s11206-005-9057-0

Giesen, E., Berman, S., Bell, R., \& Blitz, A. (2007). Three ways to successfully innovate your business model. Strategy and Leadership, 35, 27-33.

Gordijn, J. (2002). Value-based requirements engineering: Exploring innovative e-commerce ideas. Amsterdam: Free University Netherland.

Hedman, J., \& Kalling, T. (2003). The business model concept: theoretical underpinnings and empirical illustrations. European Journal of Information Systems, 12, 49-59. http://dx.doi.org/10.1057/palgrave.ejis.3000446

Johnson, M., Christensen, C., \& Kagermann, H. (2008). Reinventing your business model. Hardvard Business Review, 86(12), 50-59. http://dx.doi.org/10.1007/978-3-540-70887-2_20

Kim, S., \& Im, K. (2012). Business model characterization by analyzing business model components of Patenet Data. Applied Mathematics \& Information Sciences, 6(1), 303-309.

Krcmar, H., Bohm, M., Friesike, S., \& Schildhauer, T. (2011). Innovation, society and business: internet based business models and their implications. 1st Berlin Symposium on Internet and Society.

Magretta, J. (2002). Why business models matter. Harvard Business Review, 80(5), 86-93. 
Mahadevan, B. (2000). Business models for internet based E-commerce: an anatomy. California Management Review, 42(4), 55-69.

Makinen, S., \& Seppanen, M. (2007). Assessing business model concepts with taxonomical research criteria: A preliminary study. Management Research News, 30(10), 735-748. http://dx.doi.org/10.1504/IJMCP.2007.015133

Mason, K., \& Spring, M. (2010). The sites and practices of business models. Industrial Marketing Management, 40, 1032-1041.

Morris, M., Schidehutte, M., \& Allen, J. (2005). The entrepreneur's business model: Toward a unified perspective. Journal of Business Research, 58(6), 726-735. http://dx.doi.org/10.1016/j.jbusres.2003.11.001

Osterwalder, A. (2004). The business model ontology: A proposition in a design science approach. University of Lausanne Ecole des Hautes Etudes Commerciales.

Osterwalder, A., \& Pigneir, Y. (2002). An e-business model ontology for modeling e-business. 15th Bled Electronic Commerce Conference e-Reality: Constructing the e-economy. Slovenia.

Osterwalder, A., \& Pigneur, Y. (2010). Business Model Generation: A handbook for visioneries, game changers, and challangers. John Wiley \& Sons.

Osterwalder, A., Pigneir, Y., \& Tucci, C. (2005). Clarifying business models: Origins, present, future of the concept. Communications for the Association for Information Systems, 15.

Palo, T., \& Tahtinen, F. (2011). A network perspective on business models for emerging technology based service. Journal of Business \& Industrial Marketing, 26(5), 377-388. http://dx.doi.org/10.1108/08858621111144433

Pateli, A. G., \& Giaglis, G. M. (2003). A framework for understanding and analysing e-business model. 16th Bled e-commerce conference e-transformation. Slovenia.

Pauwels, K., \& Weiss, A. (2008). Moving from free to free: How online firms market to change their business model successfully. Journal of Marketing, 72, 14-31. http://dx.doi.org/10.1509/jmkg.72.3.14

Rappa, M. (2001). Managing the digital enterprise: Business models on the web. Retrieved March Wednesday, 2012, from www.digitalenterprise.org: http://digitalenterprise.org/models/models.html

Seddon, P., Lewis, G., Freeman, P., \& Shanks, G. (2004). The case for viewing business models as abstractions of strategy. Communication of the Association for Information System, 427-442. http://dx.doi.org/10.1016/B978-075066140-9/50004-7

Shafer, S., Smith, H., \& Linder, J. (2005). The power of business models. Business Horizons, 48, 199-207. http://dx.doi.org/10.1016/j.bushor.2004.10.014 
Tapscott, D. (2001). Rethinking strategy in a networked world: Or why micheal porter is wrong about the internet strategy. Strategy and Business, 24, 1-8.

Tapscott, D., Ticoll, D., \& Lowy, A. (2000). Digital captial: Harnessing the power of business webs. Cambridge: Harvard Business School Press. http://dx.doi.org/10.1145/334425.334434

Teece, D. (2010). Business models, Business strategy and Innovation. Long Range Planning, 43(2-3), 172-194. http://dx.doi.org/10.1016/j.lrp.2009.07.003

Timmers, P. (1998). Business models for electronic markets. Electronic Markets, 8(2), 172-194. http://dx.doi.org/10.1080/10196789800000016

Weill, P., \& Vitale, M. (2002). What IT infrastructure capabilities are needed to implement E-business models. MIS Quarterly Executive, 1(1), 17-34.

Weill, P., \& Vitale, M. R. (2001). Place to Space: Migrating to E-business Models. Harvard Business Press.

Weill, P., Malone, T., \& Apel, T. (2011). The business models investors prefer. MIT Sloan Management Review, 52(4), 17-19.

Weiner, N., Renner, T., \& Kett, H. (2010). The internet business models in services: current state of research and practice. Stuttgart: Franunhofer Verlag.

Welge, M., \& AL-Laham, A. (2003). Strategic Managment" Principle, process, implementation (4 ed.). Gabler. http://dx.doi.org/10.1007/978-3-322-99748-7_1

Zott, C., Amit, R., \& Massa, L. (2010). The business model: Theoretical roots, recent developments and future research. IESE Business School-University of Nawarra.

Appendix I (Variety of business model definitions from 1998 to 2010)

\begin{tabular}{|l|l|l|}
\hline Author's Name & Year & Description \\
\hline Timmers & 1998 & $\begin{array}{l}\text { Business model is architecture of the product or service and information } \\
\text { flow including description of actors, benefits, and revenue. }\end{array}$ \\
\hline Rappa & 2000 & $\begin{array}{l}\text { Business model describe the revenue generation perspective and } \\
\text { positioning in the value chain }\end{array}$ \\
\hline Mahadevan & 2000 & $\begin{array}{l}\text { Business model based on the main three stream including players, } \\
\text { revenue and logistics }\end{array}$ \\
\hline Tapscott & 2001 & $\begin{array}{l}\text { Business model elucidate the firm architecture for creation of customer } \\
\text { value. }\end{array}$ \\
\hline Amit \& Zott & 2001 & $\begin{array}{l}\text { Business model based on innovation in which business opportunities } \\
\text { captured through value creation }\end{array}$ \\
\hline Gordijn \& Akkermans & 2001 & $\begin{array}{l}\text { Design e3- value that describes exchange of economic value with } \\
\text { network. }\end{array}$ \\
\hline Afuah and Tucci & 2001 & Firm utilize their resource to provide better vallue to customer and in \\
\hline
\end{tabular}




\section{Macrothink}

Journal of Management Research

ISSN 1941-899X

2012, Vol. 4, No. 4

\begin{tabular}{|c|c|c|}
\hline & & $\begin{array}{l}\text { return gain profit, therefore firms have to perform better than their } \\
\text { competitors do. }\end{array}$ \\
\hline Weill and Vitale & 2001 & $\begin{array}{l}\text { Business model provide description of different actors role, which } \\
\text { influence the flows including product, information, and money in the } \\
\text { network. }\end{array}$ \\
\hline $\begin{array}{l}\text { Chesbrough } \\
\text { Rosenbloom }\end{array}$ & 2002 & Business model transfer the technology into economic values \\
\hline Osterwalder et al. & 2002 & $\begin{array}{l}\text { Business model only provide description of firm architecture and its } \\
\text { network for creation and delivery of value to one or group of customers. }\end{array}$ \\
\hline Magretta & 2002 & $\begin{array}{l}\text { Business model is a framework which give answer the question of who, } \\
\text { what, how (Peter Drucker's age old questions) }\end{array}$ \\
\hline Hedman \& Kalling & 2003 & $\begin{array}{l}\text { Describe the key elements of business and also enlighten culture } \\
\text { constraints }\end{array}$ \\
\hline Osterwalder & 2004 & $\begin{array}{l}\text { Business model is a conceptual tool that describes the company logic } \\
\text { through group of elements and their relationship. }\end{array}$ \\
\hline Morris et al. & 2005 & $\begin{array}{l}\text { Present decision variable group which interrelated the strategy, } \\
\text { architecture and economics for sustainability }\end{array}$ \\
\hline Osterwalder et al. & 2005 & $\begin{array}{l}\text { Business model describe the value of company offer through set of } \\
\text { elements and their relationship }\end{array}$ \\
\hline Shafer et al. & 2005 & Explain how values create and capture in a value network \\
\hline Chesbrough & 2006 & $\begin{array}{l}\text { Value creation and value capturing are two main functions of business } \\
\text { model. }\end{array}$ \\
\hline $\begin{array}{l}\text { Bouwman, De Vos and } \\
\text { Haaker }\end{array}$ & 2008 & $\begin{array}{l}\text { In service industry, business model describe the value of targeted group, } \\
\text { which act as source of revenue and architecture of delivering service. }\end{array}$ \\
\hline Westerlund et al. & 2008 & $\begin{array}{l}\text { Business generates revenue through specifying the relationship in } \\
\text { network is called business model. }\end{array}$ \\
\hline $\begin{array}{l}\text { Johson, Christensen and } \\
\text { Kagermann }\end{array}$ & 2008 & $\begin{array}{l}\text { Business model build up with four elements including value } \\
\text { proposition, profit formula, processes and resources. }\end{array}$ \\
\hline Mullins and Komisar & 2009 & Business model refer to the economic activities of business. \\
\hline Osterwalder and Pigneur & 2010 & $\begin{array}{l}\text { Business model describe the how create, delivers and capture the value } \\
\text { by organization. }\end{array}$ \\
\hline $\begin{array}{l}\text { Casadesus-Masanell et } \\
\text { al. }\end{array}$ & 2010 & Business model describe the firm realized strategy \\
\hline Amit and Zott & 2010 & $\begin{array}{l}\text { Business model is description of activity systems how firm deliver value } \\
\text { to different players and how connect with product markets. }\end{array}$ \\
\hline Demil and Lecocq & 2010 & $\begin{array}{l}\text { Business model used to produce proposition that generate the value for } \\
\text { customer and organization. }\end{array}$ \\
\hline Teece & 2010 & Articulation of logic and evidence for value proposition \\
\hline
\end{tabular}


Appendix II (Diverse business model components from 1998-2010)

\begin{tabular}{|c|c|c|}
\hline $\begin{aligned} \text { Timmer, } & 1998 \\
\text { - } & \text { Architecture } \\
\text { - } & \text { Information flow } \\
\text { - } & \text { Benefits to actors } \\
\text { - } & \text { Revenue }\end{aligned}$ & $\begin{aligned} \text { Wirtz, } & 2000 \\
\text { - } & \text { Market } \\
\text { - } & \text { Procurement } \\
\text { - } & \text { Performance creation } \\
\text { - } & \text { Distribution } \\
\text { - } & \text { Capital }\end{aligned}$ & $\begin{aligned} & \text { Mahadevan, } 2000 \\
& \text { - } \text { Value stream } \\
& \text { - } \text { Revenue stream } \\
& \text { - } \text { Logistical stream }\end{aligned}$ \\
\hline $\begin{array}{cl}\text { Hamel, } & 2000 \\
\text { - } & \text { Customer interface } \\
\text { - } & \text { Core strategy } \\
\text { - } & \text { Strategic Resources } \\
\text { - } & \text { Value network } \\
\text { - } & \text { Wealth potential }\end{array}$ & $\begin{aligned} & \text { H. D. Zimmerman, } 2000 \\
& \text { • } \text { Product } \\
& \text { • } \text { Process } \\
& \text { - } \text { Structure }\end{aligned}$ & $\begin{aligned} & \text { Stewart, Zhao, } 2000 \\
& \text { - } \text { Customer selection } \\
& \text { - } \text { Value capture } \\
& \text { - } \text { Differentiation and } \\
& \text { strategies control } \\
& \text { - } \text { Scope }\end{aligned}$ \\
\hline $\begin{array}{cl}\text { Buchholz \& Bech, } 2001 \\
\text { - } & \text { Processes } \\
\text { - } & \text { Transaction } \\
\text { - } & \text { Participants } \\
\text { - } & \text { Proceeds }\end{array}$ & $\begin{array}{l}\text { Staehler, } 2001 \\
\text { - } \quad \text { Value proposition } \\
\text { - } \\
\text { - } \\
\text { Architecture } \\
\text { Creation yield }\end{array}$ & 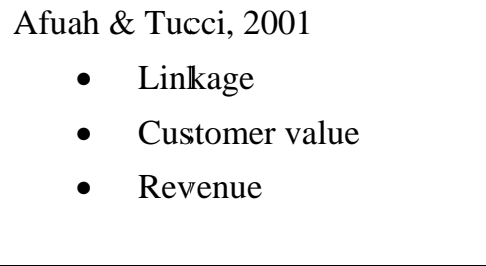 \\
\hline $\begin{aligned} \text { Rapp, } & 2001 \\
\text { - } & \text { Sustainability } \\
\text { - } & \text { Revenue stream } \\
\text { - } & \text { Cost structure } \\
\text { - } & \text { Value chain positioning }\end{aligned}$ & $\begin{array}{l}\text { Applegate, } 2001 \\
\text { - } \text { Concept (strategic) } \\
\text { - } \quad \text { Capabilities (people) } \\
\text { - } \quad \text { Value (benefits return to } \\
\quad \text { firm) }\end{array}$ & $\begin{aligned} & \text { Alt \& } \text { Zimmerman, } 2001 \\
& \text { - } \text { Misision (values) } \\
& \text { - } \text { Structure (actors) } \\
& \text { - } \text { Processes (customers) } \\
& \text { - } \text { Revenue } \\
& \text { - } \text { Legal Issue } \\
& \text { - } \text { Technology } \\
&\end{aligned}$ \\
\hline $\begin{array}{cl}\text { Osterwalder, } 2004 \\
\text { - } & \text { Value proposition } \\
\text { - } & \text { Customer segment } \\
\text { - } & \text { Partner network } \\
\text { - } & \text { Delivery channel } \\
\text { - } & \text { Revenue stream }\end{array}$ & 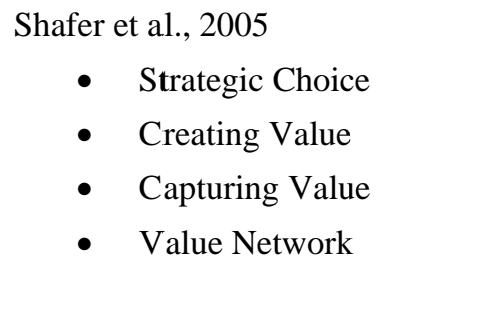 & $\begin{aligned} & \text { Morris et al., } 2005 \\
& \text { • } \text { Economics } \\
& \text { • } \text { Operational } \\
& \text { - } \text { Strategic Model }\end{aligned}$ \\
\hline $\begin{array}{l}\text { Osterwalder et al., } 2005 \\
\text { - } \quad \text { Value proposition } \\
\text { - } \quad \text { Target Customer } \\
\text { - } \quad \text { Distribution channels } \\
\text { - } \quad \text { Relationship } \\
\text { - } \quad \text { Value configuration } \\
\text { - } \quad \text { Core competencies } \\
\text { - } \quad \text { Partner network } \\
\text { - } \quad \text { Cost structure } \\
\text { - }\end{array}$ & $\begin{array}{l}\text { Brousseau \& Penard, } 2006 \\
\text { - } \\
\text { - } \\
\text { - } \\
\text { Revent Structure } \\
\text { Sustainable income } \\
\text { - } \text { generation } \\
\text { Good/ service production } \\
\text { and exchange }\end{array}$ & $\begin{aligned} & \text { Bonaccorsi et al., } 2006 \\
& \text { - } \text { Product/Service delivery } \\
& \text { - } \text { Customers } \\
& \text { - } \text { Cost structure } \\
& \text { - } \text { Income } \\
& \text { - }\end{aligned}$ \\
\hline Johnson et al., 2008 & Pieter Ballon, 2007 & Chesbrough et al., 2009 \\
\hline
\end{tabular}




\begin{tabular}{|c|c|c|}
\hline $\begin{array}{ll}\text { - } & \text { Customer value } \\
\text { - } & \text { Proposition } \\
\text { - } & \text { Key resources } \\
\text { - } & \text { Key processes }\end{array}$ & 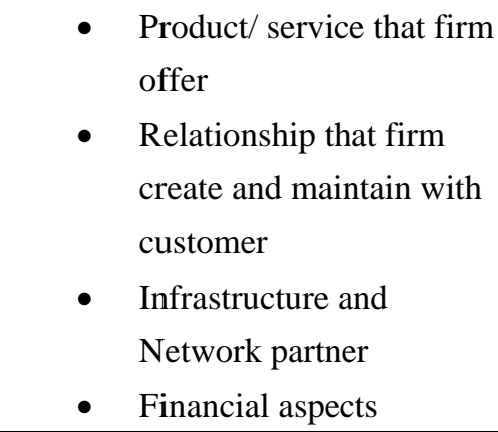 & $\begin{array}{ll}\text { - } & \text { Infrastructure (key } \\
\text { partner, activities, } \\
\text { - } & \text { resources) } \\
\text { - } & \text { Culue proposition } \\
\text { - } & \text { Finannels, segment) } \\
\text { structure) }\end{array}$ \\
\hline $\begin{array}{l}\text { Doganova et al., } 2009 \\
\text { • } \\
\text { - } \\
\quad \text { Architecture of value } \\
\text { Revenue model }\end{array}$ & $\begin{array}{l}\text { Mason \& Spring, } 2010 \\
\text { • } \\
\text { - } \quad \text { Technology } \\
\text { - } \quad \text { Market Offering }\end{array}$ & \\
\hline
\end{tabular}




\section{Macrothink}

Journal of Management Research

ISSN 1941-899X

2012, Vol. 4, No. 4

Appendix III (Chronological business model building blocks from 1996-2010)

\begin{tabular}{|c|c|c|c|c|c|c|c|c|c|c|c|c|c|c|c|c|c|c|c|c|c|c|c|c|c|c|c|c|}
\hline $\begin{array}{l}\text { Chronolo } \\
\text { gical } \\
\text { Author's } \\
\text { Name }\end{array}$ & 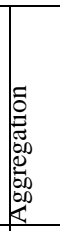 & 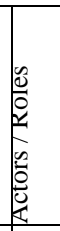 & 音 & 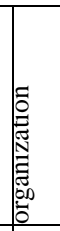 & 3 & 茯 & 若 & 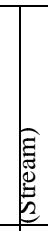 & 总 & 罳 & 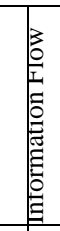 & 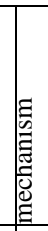 & 造 & 飠 & 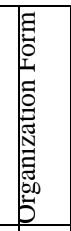 & 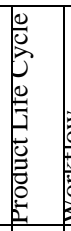 & \begin{tabular}{|l} 
\\
3 \\
0 \\
3 \\
3 \\
3 \\
3
\end{tabular} & 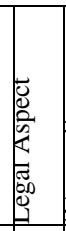 & 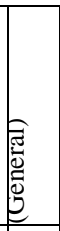 & 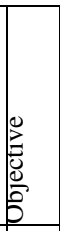 & 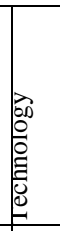 & | & 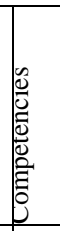 & 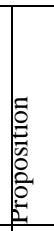 & 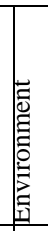 & لـ & 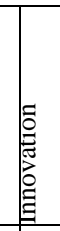 & 要 \\
\hline $\begin{array}{l}\text { Baatz } \\
(1996)\end{array}$ & & & & & & & & & 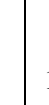 & & & & & & & & & & & & & & & & & & & \\
\hline $\begin{array}{l}\text { Osterle } \\
\text { (1996) }\end{array}$ & & & & & & & & & & & & & 1 & & & & & & & & & 1 & & & & & & \\
\hline
\end{tabular}

Carroll

und

Trebnick

(1997)

1

Timmers

\begin{tabular}{|l|l|l|l|l|l|l|l|l|l|l|} 
(1998) & 1 & & & & 1 & & 1 & 1 & & \\
\hline
\end{tabular}

\section{Lindstro}

m (1999) 1

Nilsson,

Tolis und

Nellborn

(1999)

\begin{tabular}{l|l|l|l|l|l|l|l} 
Willars & & & & & \\
\hline
\end{tabular}

(1999) 11

Bartelt

und

Lamersd

orf

\begin{tabular}{|l|l|l|l|l|l|l|l|l|l|l|l|}
\hline (2000) & 1
\end{tabular}

\section{Eriksson,}

Penker

(2000) 1

Heinrich

und Leist

\begin{tabular}{l|l|l|l|l|l|l|l}
$(2000)$ & & 1 & & 1 & & & 1 \\
\hline
\end{tabular}

\begin{tabular}{|l|l|l|l|l|l|l|l|l|l|l|l|l|l|}
\hline Wirtz & & & & & & & & & & & & & \\
\hline
\end{tabular}

\begin{tabular}{|l|l|l|l|l|l|l|l|l|l|l|l|l|l|l|l|l|l|l|l|l|l|l|l|l|l|l|}
\hline $\begin{array}{l}\text { Hamel } \\
(2000)\end{array}$ & & 1 & 1 & & & & & 1 & & & & 1 & & & & 1 & & 1 & & & & & 1 & 1 & & \\
\hline $\begin{array}{l}\text { Klueber } \\
(2000)\end{array}$ & 1 & 1 & & 1 & 1 & & & 1 & 1 & 1 & & 1 & & & & & & & & 1 & 1 & & \\
\hline $\begin{array}{l}\text { Stewart } \\
\text { et. }\end{array}$
\end{tabular}




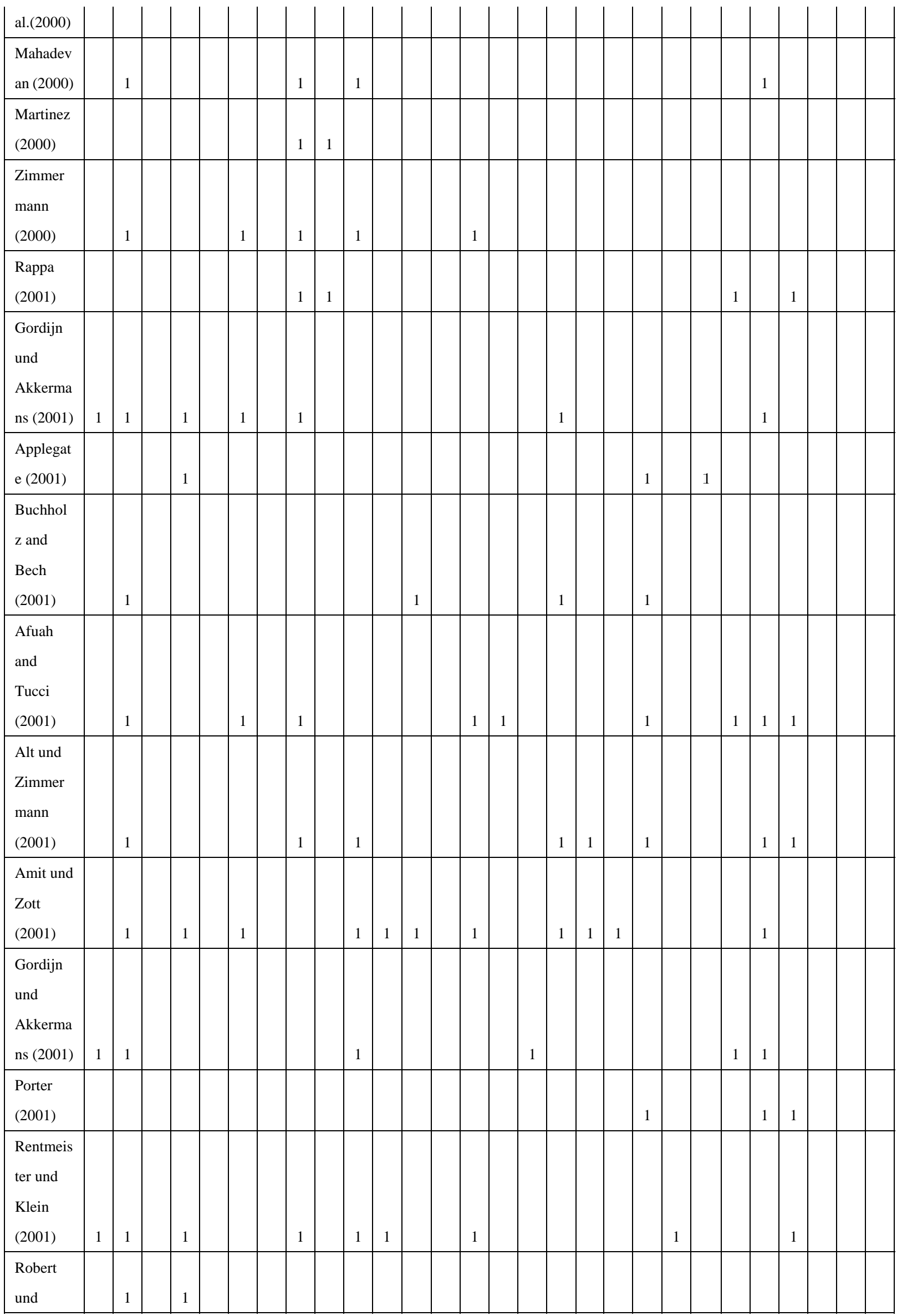




\begin{tabular}{|c|c|c|c|c|c|c|c|c|c|c|c|c|c|c|c|c|c|c|c|c|c|c|c|c|c|c|}
\hline \multicolumn{27}{|c|}{$\begin{array}{l}\text { Racine } \\
\text { (2001) }\end{array}$} \\
\hline $\begin{array}{l}\text { Weill } \\
\text { und } \\
\text { Vitale } \\
\text { (2001) }\end{array}$ & 1 & 1 & 1 & 1 & & 1 & & 1 & & 1 & 1 & 1 & 1 & & & & & & 1 & & & 1 & & & & \\
\hline $\begin{array}{l}\text { Bieger, } \\
\text { et al. } \\
\text { (2002) }\end{array}$ & 1 & 1 & & 1 & & & 1 & 1 & 1 & 1 & & & & & & & & & 1 & & 1 & 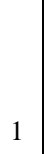 & & 1 & & \\
\hline $\begin{array}{l}\text { Bieger, } \\
\text { Ruegg- } \\
\text { Sturm } \\
\text { und Rohr } \\
\text { (2002) }\end{array}$ & & 1 & 1 & 1 & 1 & 1 & 1 & 1 & & & & & & 1 & & & & & & & 1 & 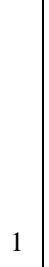 & 1 & & & \\
\hline $\begin{array}{l}\text { Ray Poot } \\
\text { (2002) }\end{array}$ & & 1 & & & & & 1 & 1 & & 1 & & & & & & & & & & & & & 1 & & & \\
\hline $\begin{array}{l}\text { Dubosso } \\
\text { nett } \\
\text { (2002) }\end{array}$ & & 1 & 1 & 1 & & 1 & & 1 & & & & & & & & 1 & & 1 & & & & . & 1 & 1 & 1 & \\
\hline $\begin{array}{l}\text { Chesbro } \\
\text { ugh, } \\
\text { Rosenblo } \\
\text { om } \\
\text { (2002) }\end{array}$ & & & & & & & & & & & & & & & & & & 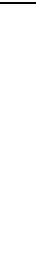 & & 1 & & & 1 & . & & 1 \\
\hline $\begin{array}{l}\text { Hoque } \\
\text { (2002) }\end{array}$ & & 1 & & 1 & & & 1 & 1 & & 1 & & & & & & & 1 & 1 & 1 & 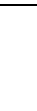 & & 1 & 1 & & & \\
\hline $\begin{array}{l}\text { Magretta } \\
\text { (2002) }\end{array}$ & & 1 & & 1 & & & & & 1 & & & & & & & & & 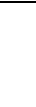 & & & & 1 & 1 & & & \\
\hline $\begin{array}{l}\text { Mercer } \\
\text { (2002) }\end{array}$ & & & & & & & & & 1 & 1 & & & & 1 & & & & 1 & 1 & & & & & 1 & & \\
\hline $\begin{array}{l}\text { Osterwal } \\
\text { der und } \\
\text { Pigneur } \\
\text { (2002) }\end{array}$ & & 1 & & 1 & & 1 & & 1 & & 1 & & & & & 1 & & & . & & 1 & & & 1 & & & \\
\hline $\begin{array}{l}\text { Schogel } \\
(2002)\end{array}$ & 1 & & & 1 & & & & 1 & & 1 & & & & & & 1 & 1 & 1 & 1 & 1 & & & 1 & 1 & & \\
\hline $\begin{array}{l}\text { Servatius } \\
\text { (2002) }\end{array}$ & & 1 & 1 & & & & & 1 & 1 & & & & & & & 1 & & 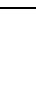 & & & & & 1 & & & \\
\hline $\begin{array}{l}\text { Stahler } \\
\text { (2002) }\end{array}$ & & 1 & & 1 & & & & 1 & & & & & 1 & & & & & & & & & 1 & 1 & & & \\
\hline $\begin{array}{l}\text { Chesbro } \\
\text { ugh } 2003\end{array}$ & & 1 & & & & & & & & & & & & & & & & & 1 & & & & 1 & 1 & & \\
\hline Van & & 1 & & 1 & & & & & & & & & & & & 1 & & 1 & & & & & & & 1 & 1 \\
\hline
\end{tabular}




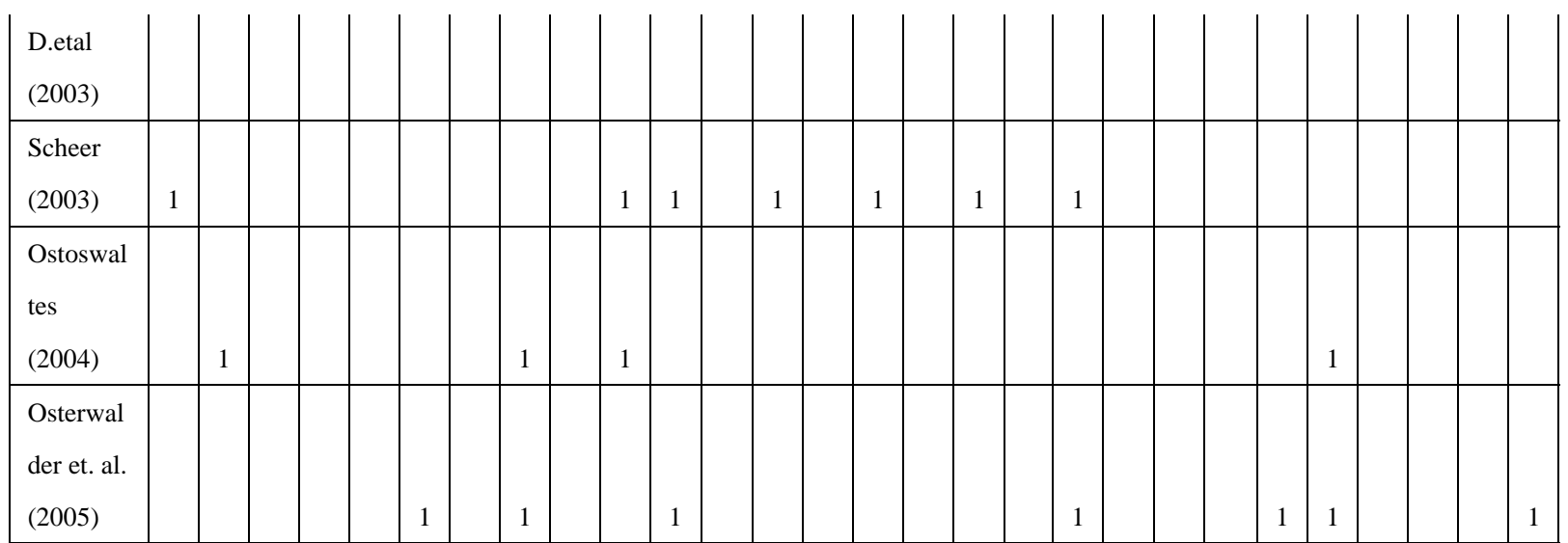

\section{Morris et}

al.

\begin{tabular}{l|l|l|l|l} 
(2005) & 1 & & \\
\hline
\end{tabular}

1

$1 \quad 1$

1

\begin{tabular}{l|l|l}
1 & 1 & 1
\end{tabular}

Shafer et

al.

(2005)

$1 \quad 1$

1

\begin{tabular}{l|l}
1 & 1
\end{tabular}

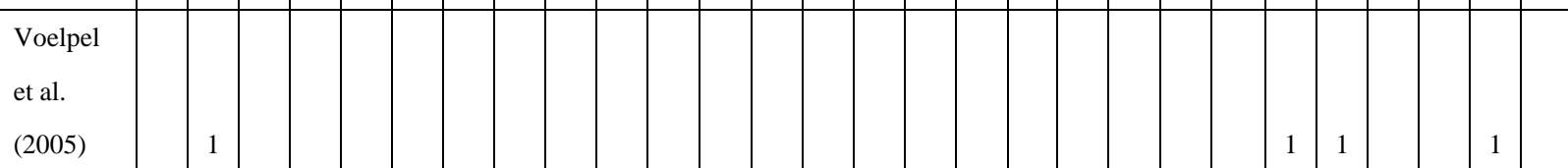

\section{Bronssea}

$\mathrm{u}$ and

Penord

(2006)

\begin{tabular}{l|l|l}
1 & 1 & 1
\end{tabular}

\section{Bonacors}

$i$ et. at.

(2006)

11

1

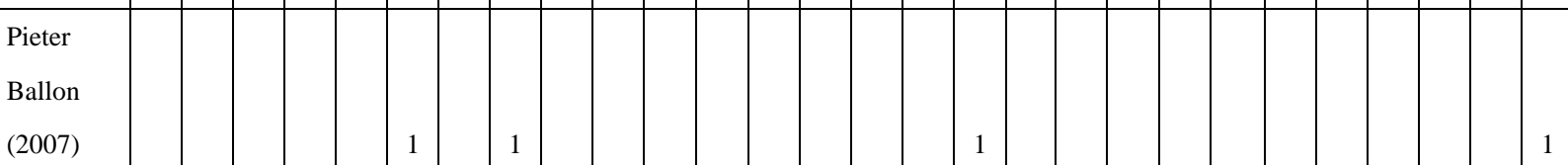

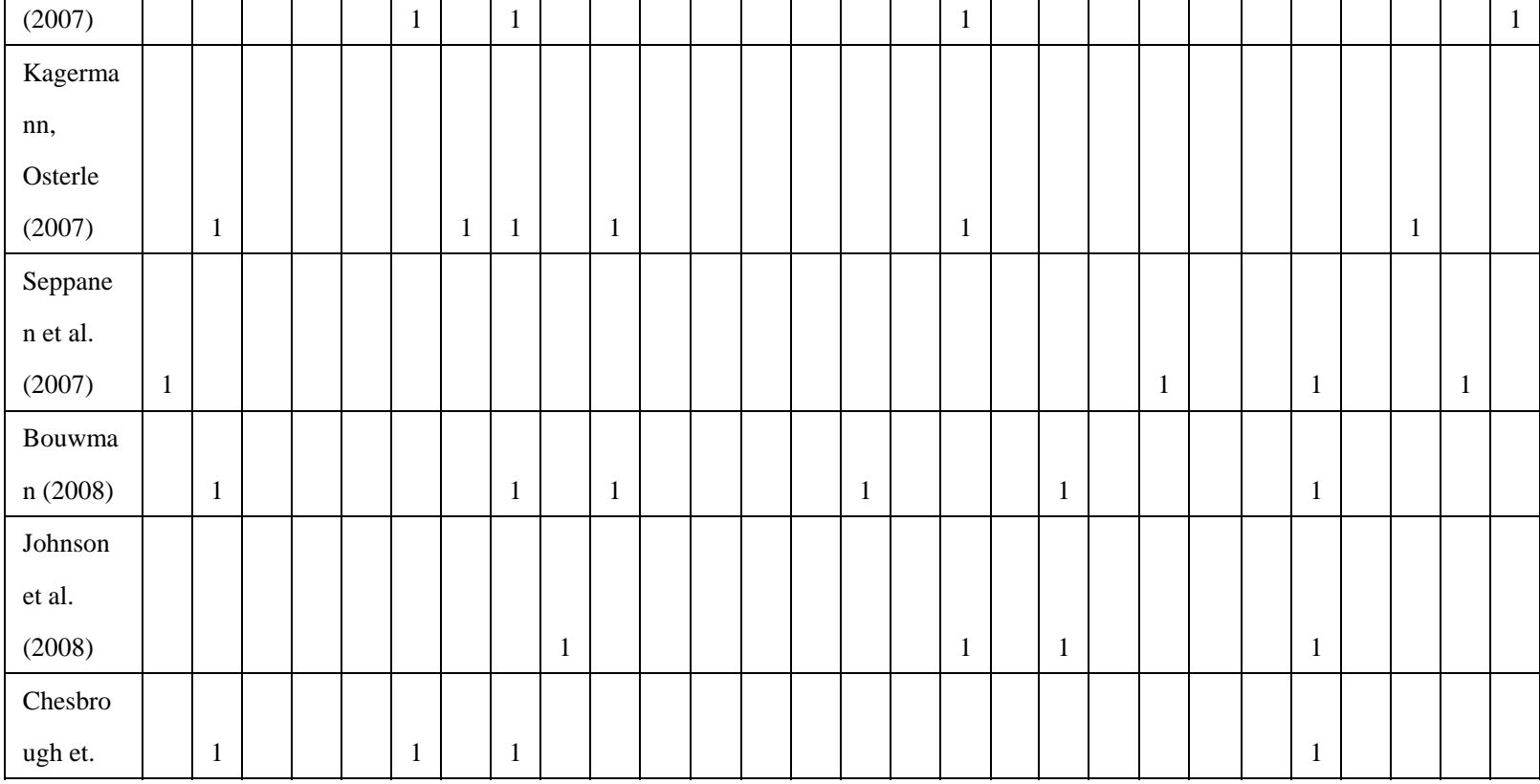




MlMacrothink

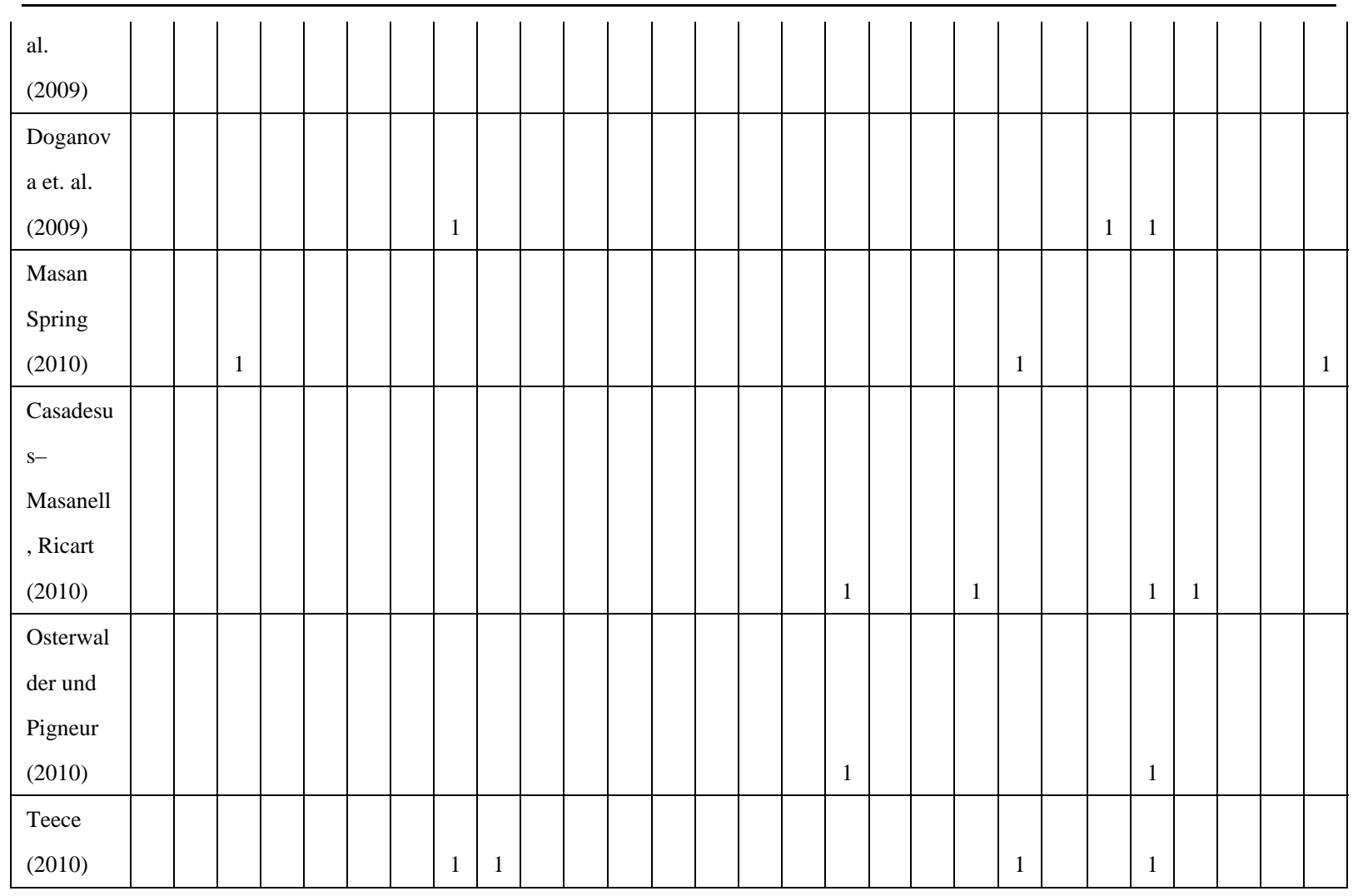


Appendix IV (Tally Marks and Frequency Distribution of Business Model Components)

\begin{tabular}{|c|c|c|}
\hline Building Blocks & Tally & Frequency \\
\hline Abstraction / Aggregation & 世世 Ш世 IIII & 14 \\
\hline Actors / Roles & 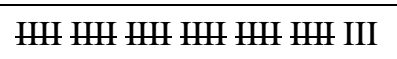 & 33 \\
\hline Competitive environment & 世世 世世 Ш世 & 15 \\
\hline Culture/ Control Mechanism & IIII & 4 \\
\hline Critical Success Factors & IIII & 4 \\
\hline External Communication Concept & 世世 III & 7 \\
\hline Finance / Revenue (streams) & Ш Ш世 Ш世 Ш世 Щ世 Ш世 IIII & 34 \\
\hline Focus on Business Unit & HII III & 7 \\
\hline Focus on Business Web \& Identity & IIII & 4 \\
\hline Focus on Organization \& reputation & ШШ НШ ШШ ШШ I & 21 \\
\hline Growth & IIII & 4 \\
\hline Information (stream) & HII III & 8 \\
\hline Innovation & 世世 & 5 \\
\hline Leadership & III & 3 \\
\hline Legal and Economic Aspects & 世 & 5 \\
\hline Organizational Form & 世世 III & 8 \\
\hline Processes / Workflow & Щ Ш世 Ш世 III & 18 \\
\hline Product / Service (streams) & 世 世世 Ш世 Щ世 I & 21 \\
\hline Product Lifecycle & IIII & 4 \\
\hline Profit & ШШ HЕ II & 12 \\
\hline Relationship of Actors & 世世 $\amalg$ I & 11 \\
\hline Resources (general) & 世 世 & 10 \\
\hline Strategy / Vision / Objective & 世 Щ世 世 II & 17 \\
\hline Technology & 世世 世 & 10 \\
\hline Utility & 世II IIII & 9 \\
\hline Value Chain / Core Competences & 世 世 世 II & 17 \\
\hline Value Creation/Proposition & 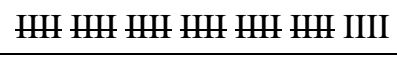 & 34 \\
\hline Value Network & 世 I & 6 \\
\hline
\end{tabular}

